\title{
Penentuan Ekstrakurikuler Siswa Sesuai Minat Bakat dengan Case-Based Reasoning dan Certainty Factor
}

\author{
http://dx.doi.org/10,28932/jutisi.v7i3.4011 \\ Riwayat Artikel
}

Received: 25 September 2021 | Final Revision: 30 November 2021 | Accepted: 30 November 2021

\author{
Arjun Sirojul Anam ${ }^{\bowtie \# 1}$, Faris Muslihul Amin ${ }^{* 2}$, Mujib Ridwan ${ }^{\# 3}$ \\ \# Jurusan Sistem Informasi, UIN Sunan Ampel Surabaya \\ Jl. Ahmad Yani No.117, Jemur Wonosari, Kec. Wonocolo, Surabaya, Jawa Timur 60237

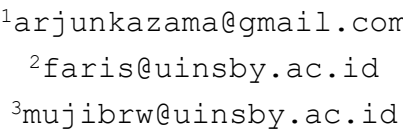

\begin{abstract}
Extracurricular activities at MAN 1 Lamongan are still determined without any support from the system. Students are only given extracurricular information and can register according to the conditions if interested. This makes the extracurricular that students have chosen does not fully match their abilities. The result is a decrease in the number of members who are active in extracurricular activities due to loss of interest. A web-based system was developed to assist MAN 1 Lamongan in determining extracurricular according to interests and talents. Case-Based Reasoning (CBR) is the system framework and Certainty Factor $(\mathrm{CF})$ is the algorithm for determining the certainty value. The result is that with test data of 68 students, the system recommends extracurricular well. Testing with Confusion Matrix obtained precision level of $96.03 \%$ (high), recall of $99.4 \%$ (high), accuracy of $95.76 \%$ (high).
\end{abstract}

Keywords - Case-Based Reasoning; Certainty Factor; Decision Support System; Extracurricular; Interest and Talents.

\section{Pendahuluan}

Ekstrakurikuler berhubungan dengan penerapan dari ilmu yang diperoleh siswa dengan kesesuaian terhadap lingkungan sekitar dan tuntunan kehidupan saat ini [1]. Menteri Pendidikan dan Kebudayaan Nasional dalam peraturannya No. 62 tahun 2014 menerangkan bahwa penyelenggaraan kegiatan ekstrakurikuler berfungsi untuk pengembangan potensi dari minat dan bakat siswa dalam rangka mensukseskan pendidikan nasional [2]. Ekstrakurikuler yang sesuai dengan minat bakat siswa menjadi hal yang penting karena terkait dengan pengembangan pendidikan yang sesuai dengan kebutuhan hidup dan lingkungan pembelajarannya. Minat dan bakat yang ada pada diri masing-masing siswa harus diarahkan. Oleh karena itu minat dan bakat siswa harus diketahui institusi pendidikan yang diwadahi dalam kegiatan ekstrakurikuler [3].

Madrasah Aliyah Negeri (MAN) 1 Lamongan merupakan institusi pendidikan di bawah Kementerian Agama. MAN 1 Lamongan berlokasi di Jalan Veteran No. 43, Kabupaten Lamongan, Jawa Timur. Sekolah yang didirikan pada 1980 ini memiliki 17 kegiatan ekstrakurikuler yang dapat diikuti untuk mengembangkan potensi. Ekstrakurikuler yang tersedia di MAN 1 Lamongan adalah pramuka, futsal, karya ilmiah remaja (KIR), gambus, drumband, basket, palang merah remaja (PMR), teater, patroli keamanan sekolah (PKS), bulu tangkis, voli, banjari, pecinta alam (pala), paduan suara (padus), paskib, band, dan musabaqoh tilawatil quran (MTQ) [4]. Agar bisa bergabung di salah ekstrakurikuler, siswa mengisi formulir pendaftaran dan memahami ketentuan serta syarat yang berlaku. Ada ekstrakurikuler yang memberikan persyaratan tertentu yang harus dipenuhi dan ada juga yang bisa menerima langsung.

Studi pendahuluan dilakukan pada 20-24 Maret 2020 dengan melakukan wawancara secara online pada beberapa siswa MAN 1 Lamongan. Informasi yang didapat adalah anggota aktif ekstrakurikuler mengalami penurunan di tengah tahun ajaran. Beberapa faktor yang menyebabkan turunnya jumlah anggota aktif ekstrakurikuler adalah jam latihan yang terlalu panjang, kegiatan ekstrakurikuler tidak sesuai keinginan, dan kemampuan yang tidak sesuai. Tentunya penurunan jumlah anggota aktif sangat disayangkan karena siswa tidak bisa menggunakan waktu dengan maksimal untuk mengembangkan potensi minat dan 
bakat yang dimiliki. Dari faktor-faktor yang terjadi, MAN 1 Lamongan perlu untuk melakukan evaluasi dalam penentuan ekstrakurikuler siswa agar mendapatkan rekomendasi terbaik sesuai dengan minat dan bakatnya.

Sebuah sistem pendukung keputusan (SPK) dapat digunakan untuk menentukan rekomendasi ekstrakurikuler siswa MAN 1 Lamongan berdasarkan minat dan bakat. SPK adalah sistem yang merekomendasikan solusi dari suatu masalah dengan data dan model yang dioperasikan dengan komputer [5]. Gambar 1 menunjukkan komponen SPK yang terdiri dari 4 komponen yaitu data management (tempat penyimpanan masalah), model management (memberikan fungsi perhitungan), communication / dialog management (komponen untuk berkomunikasi dengan pengguna), knowledge management (mengelola pengetahuan dan memperbarui informasi).

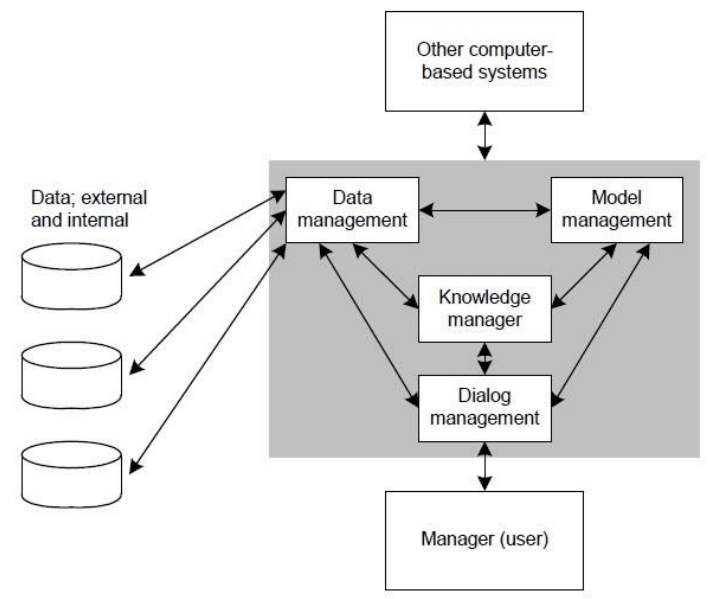

Gambar 1. Komponen SPK [5]

Karakteristik ekstrakurikuler akan disesuaikan dengan minat dan bakat siswa serta hasilnya akan dihitung untuk mendapatkan nilai persentase yang sesuai. Sistem tersebut menyimpan semua keputusan yang menjadi bahan evaluasi parameter jika ada kasus baru untuk penyesuaian ke depannya. Case-Based Reasoning (CBR) bisa diterapkan sebagai kerangka sistem dan Certainty Factor (CF) diterapkan untuk menghitung nilai kepastian setiap variabel.

CBR mempunyai basic knowledge atau pengetahuan dasar yang bisa dibandingkan dengan kasus baru [6]. Ada 4 fase dalam metode CBR yaitu retrieve (pengguna memasukkan kasus baru selanjutnya sistem akan mencari kesamaan pada kasus yang sudah tersimpan sebelumnya dengan membandingkan berdasarkan perhitungan $\mathrm{CF}$ ), reuse (ketika perhitungan selesai akan muncul nilai kepastian dan memunculkan informasi yang memiliki kemiripan untuk dievaluasi kesesuaiannya), revise (sistem merevisi kasus lama apakah informasi yang dihasilkan sesuai dengan yang dibutuhkan), dan retain (sistem menambahkan kasus baru ke case base berdasarkan perhitungan yang dilakukan) [7] [8].

CF dibutuhkan untuk menghitung nilai persentase dengan kepastian kasus yang dimasukkan ke dalam sistem (Batubara, 2018). Algoritma ini pertama kali diperkenalkan pada tahun 1975 oleh Shortliffe Buchanan yang sedang mengembangkan sistem pakar MYCIN. CF mengakomodasi nilai yang tidak pasti dari pakar untuk mengambil sebuah keputusan. Terdapat dua macam faktor kepastian yang dipakai yakni faktor kepastian yang didapatkan dari pakar dengan aturan dan faktor kepastian yang diisikan oleh pengguna. Faktor yang diisikan oleh pakar berarti tingkat kepercayaan pakar dalam suatu kondisi. Sedangkan faktor dari pengguna berarti tingkat kepercayaan terhadap masing-masing kondisi yang dialami. Pakar dalam penentuan keputusan terkadang mengungkapkan hal yang tidak pasti seperti "kemungkinan besar" dan "hampir pasti" [9]. Derajat nilai kepastian dan ketidakpastian akan dijumlahkan yang selanjutnya menghasilkan nilai satu [10].

Penelitian yang pernah dilakukan terdahulu tentang kombinasi CBR dan CF ini menunjukkan hasil akhir dengan akurasi yang tinggi. Rohadi [12] melakukan penelitian tentang penerapan CBR dan CF untuk mendeteksi kerusakan kamera DSLR. Pengujian dilakukan dengan 15 data uji dari data analisis pakar dan nilai akurasi yang dihasilkan 93\%. Hidayah [13] melakukan penelitian tentang rancang bangun sistem pakar diagnosis penyakit diabetes melitus berbasis mobile. Hasilnya menunjukkan bahwa gabungan CBR dan CF memiliki nilai akurasi sebesar 95,45\%. Penelitian lain dilakukan oleh Andika [14] yang mengembangkan sistem pakar diagnosis virus pada udang vannamei dengan metode CBR dan CF. Data gejalagejala penyakit yang menyebabkan kegagalan pada budidaya udang tambak didapatkan dari pakar. Nilai kepastian yang dihasilkan adalah sebesar $98.08 \%$.

Kombinasi CBR dan CF dipilih karena menunjukkan hasil yang memuaskan seperti hasil yang didapatkan pada penelitian terdahulu. Oleh karena itu pada penelitian ini mencoba untuk menerapkan CBR dan CF dalam menentukan ekstrakurikuler 
di MAN 1 Lamongan. Harapannya adalah siswa MAN 1 Lamongan bisa mendapatkan rekomendasi ekstrakurikuler yang diikuti berdasarkan minat dan bakat yang dimiliki. Informasi dari pakar ekstrakurikuler dijadikan sebagai knowledge parameter minat dan bakat yang berikutnya diterapkan pada pengembangan SPK website PHP.

\section{METODE PENELITIAN}

\section{A. Tahapan Penelitian}

Gambar 2 menunjukkan tahapan penelitian yang digunakan pada pengembangan sistem penentuan ekstrakurikuler siswa MAN 1 Lamongan

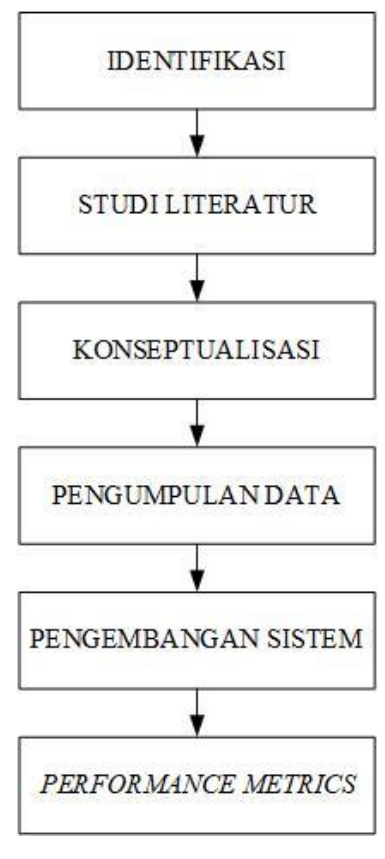

Gambar 2. Tahapan Penelitian

1. Identifikasi masalah: masalah yang teridentifikasi adalah tidak sesuainya kegiatan ekstrakurikuler yang dipilih dengan alokasi waktu, ekspektasi tidak sesuai yang diharapkan, dan kemampuan yang tidak sesuai membuat siswa menjadi kehilangan minat dalam mengikuti kegiatan ekstrakurikuler.

2. Studi literatur: menelusuri referensi yang terkait dengan penelitian serupa dan analisis sistem yang akan dibangun. Hasil studi literatur adalah metode CBR dan CF bisa diterapkan ke sebuah sistem yang memiliki tingkat keberhasilan tinggi.

3. Konseptualisasi: penentuan konsep SPK yang akan dikembangkan dengan pakar dari pembina ekstrakurikuler dan koordinator bimbingan konseling.

4. Pengumpulan data: data dikumpulkan melalui wawancara dengan media online. Data yang dikumpulkan adalah data kasus lama masing-masing ekstrakurikuler dari informasi pakar dan merujuk pada parameter fisik, kemampuan, pengetahuan dan niat [15].

5. Pengembangan sistem: SPK yang memberikan rekomendasi ekstrakurikuler berdasarkan minat dan bakat dikembangkan dengan metode waterfall [16].

6. Performance Metrics: uji akurasi untuk menghitung ketepatan sistem dalam memberikan rekomendasi ekstrakurikuler.

\section{B. Pengumpulan Data}

Data yang dikumpulkan menjadi basis pengetahuan sistem dalam memberikan rekomendasi kegiatan ekstrakurikuler. Di dalamnya terdapat variabel yang sesuai untuk kegiatan ekstrakurikuler, dan data Measure Believe (MB) serta Measure Disbelieve (MD) pada masing-masing variabel yang menjadi nilai bobot dari pakar. Nilai (MB) dan (MD) adalah hasil analisis Pakar pada sebuah variabel yang diakomodasikan menggunakan tingkat keyakinan kepercayaan dan ketidakpercayaan [9]. Setiap data variabel, Parameter dan bobot MB-MD didapatkan berdasarkan kepercayaan Pakar (setiap pembina ekstrakurikuler) pada setiap kebutuhan dalam kegiatan ekstrakurikuler tersebut. Selanjutnya data yang sudah didapat 
kemudian dikumpulkan menjadi basis pengetahuan sistem dalam memberikan rekomendasi kegiatan ekstrakurikuler. Tabel 1 adalah data kasus lama pada masing-masing kegiatan ekstrakurikuler.

TABEL 1

DATA KASUS LAMA KEGIATAN EKSTRAKURIKULER

\begin{tabular}{|c|c|c|c|c|c|}
\hline Ekstrakurikuler & Kode & Nama Variabel & Parameter & MB & MD \\
\hline \multirow[t]{8}{*}{ Teater } & 010 & Mental Kuat & Kemampuan & 0.6 & 0.4 \\
\hline & 008 & Memiliki Kepercayaan diri tinggi & Kemampuan & 0.6 & 0.4 \\
\hline & 006 & Mampu meluangkan Waktu sesuai ketentuan & Kemampuan & 0.55 & 0.45 \\
\hline & 007 & Mampu meluangkan waktu diluar ketentuan & Kemampuan & 0.55 & 0.45 \\
\hline & 015 & Mampu berakting/memiliki imajinasi tinggi & Kemampuan & 0.75 & 0.25 \\
\hline & 043 & Mengetahui program teater beserta kegiatannya & Pengetahuan & 0.6 & 0.4 \\
\hline & 044 & Mengetahui resiko dan manfaat teater & Pengetahuan & 0.6 & 0.4 \\
\hline & 077 & Niat individu dan orang tua pada bidang teater & Niat & 0.85 & 0.15 \\
\hline \multirow[t]{6}{*}{ Banjari } & 016 & Mampu memainkan alat musik banjari/menyanyikannya & Kemampuan & 0.75 & 0.25 \\
\hline & 017 & Memahami pola dan ritme musik banjari & Kemampuan & 0.7 & 0.3 \\
\hline & 006 & Mampu meluangkan Waktu sesuai ketentuan & Kemampuan & 0.55 & 0.45 \\
\hline & 045 & Mengetahui program banjari beserta kegiatannya & Pengetahuan & 0.6 & 0.4 \\
\hline & 046 & Mengetahui resiko dan manfaat banjari & Pengetahuan & 0.6 & 0.4 \\
\hline & 078 & Niat individu dan orang tua pada bidang banjari & Niat & 0.85 & 0.15 \\
\hline \multirow[t]{8}{*}{ Band } & 018 & Mampu memainkan alat musik band/menyanyikannya & Kemampuan & 0.75 & 0.25 \\
\hline & 019 & Memahami pola dan ritme musik band & Kemampuan & 0.7 & 0.3 \\
\hline & 006 & Mampu meluangkan Waktu sesuai ketentuan & Kemampuan & 0.55 & 0.45 \\
\hline & 007 & Mampu meluangkan waktu diluar ketentuan & Kemampuan & 0.55 & 0.45 \\
\hline & 008 & Memiliki Kepercayaan diri tinggi & Kemampuan & 0.6 & 0.4 \\
\hline & 047 & Mengetahui program band beserta kegiatannya & Pengetahuan & 0.6 & 0.4 \\
\hline & 048 & Mengetahui resiko dan manfaat band & Pengetahuan & 0.6 & 0.4 \\
\hline & 079 & Niat individu dan orang tua pada bidang band & Niat & 0.85 & 0.15 \\
\hline \multirow[t]{6}{*}{ Gambus } & 020 & Mampu memainkan alat musik gambus/menyanyikannya & Kemampuan & 0.75 & 0.25 \\
\hline & 021 & Memahami pola dan ritme musik gambus & Kemampuan & 0.7 & 0.3 \\
\hline & 006 & Mampu meluangkan Waktu sesuai ketentuan & Kemampuan & 0.55 & 0.45 \\
\hline & 049 & Mengetahui program gambus beserta kegiatannya & Pengetahuan & 0.6 & 0.4 \\
\hline & 050 & Mengetahui resiko dan manfaat gambus & Pengetahuan & 0.6 & 0.4 \\
\hline & 080 & Niat individu dan orang tua pada bidang gambus & Niat & 0.8 & 0.2 \\
\hline \multirow[t]{8}{*}{ Drumband } & 022 & $\begin{array}{l}\text { Mampu memainkan alat musik drumband/memainkan } \\
\text { tongkat mayoret }\end{array}$ & Kemampuan & 0.75 & 0.25 \\
\hline & 023 & Memahami pola dan ritme drumband & Kemampuan & 0.75 & 0.25 \\
\hline & 006 & Mampu meluangkan Waktu sesuai ketentuan & Kemampuan & 0.6 & 0.4 \\
\hline & 007 & Mampu meluangkan waktu diluar ketentuan & Kemampuan & 0.6 & 0.4 \\
\hline & 008 & Memiliki Kepercayaan diri tinggi & kemampuan & 0.6 & 0.4 \\
\hline & 051 & Mengetahui program drumband beserta kegiatannya & Pengetahuan & 0.6 & 0.4 \\
\hline & 052 & Mengetahui resiko dan manfaat drumband & Pengetahuan & 0.6 & 0.4 \\
\hline & 081 & Niat individu dan orang tua pada bidang drumband & Niat & 0.85 & 0.15 \\
\hline \multirow[t]{8}{*}{ Basket } & 001 & Fisik sehat & Fisik & 0.6 & 0.4 \\
\hline & 002 & Tidak memiliki cacat yang mengganggu kegiatan & Fisik & 0.55 & 0.45 \\
\hline & 003 & Tinggi diatas $165 \mathrm{~cm}$ & Fisik & 0.55 & 0.45 \\
\hline & 024 & $\begin{array}{l}\text { Mampu melakukan passing, dribbling, shooting dengan } \\
\text { bola basket }\end{array}$ & Kemampuan & 0.8 & 0.2 \\
\hline & 009 & Mampu bekerja dengan tim & Kemampuan & 0.6 & 0.4 \\
\hline & 006 & Mampu meluangkan waktu sesuai ketentuan & Kemampuan & 0.55 & 0.45 \\
\hline & 007 & Mampu meluangkan waktu diluar ketentuan & Kemampuan & 0.55 & 0.45 \\
\hline & 053 & Mengetahui program basket beserta kegiatannya & Pengetahuan & 0.6 & 0.4 \\
\hline
\end{tabular}




\begin{tabular}{|c|c|c|c|c|c|}
\hline Ekstrakurikuler & Kode & Nama Variabel & Parameter & MB & MD \\
\hline & 054 & Mengetahui resiko dan manfaat basket & Pengetahuan & 0.6 & 0.4 \\
\hline & 082 & Niat individu dan orang tua pada bidang basket & Niat & 0.85 & 0.15 \\
\hline \multirow[t]{9}{*}{ Voli } & 001 & Fisik sehat & Fisik & 0.55 & 0.45 \\
\hline & 002 & Tidak memiliki cacat yang mengganggu kegiatan & Fisik & 0.55 & 0.45 \\
\hline & 025 & $\begin{array}{l}\text { Mampu melakukan passing, servis dan smashing dengan } \\
\text { bola voli }\end{array}$ & Kemampuan & 0.8 & 0.2 \\
\hline & 009 & Mampu bekerja dengan tim & Kemampuan & 0.6 & 0.4 \\
\hline & 006 & Mampu meluangkan waktu sesuai ketentuan & Kemampuan & 0.55 & 0.45 \\
\hline & 007 & Mampu meluangkan waktu diluar ketentuan & Kemampuan & 0.55 & 0.45 \\
\hline & 055 & Mengetahui program voli beserta kegiatannya & Pengetahuan & 0.6 & 0.4 \\
\hline & 056 & Mengetahui resiko dan manfaat voli & Pengetahuan & 0.6 & 0.4 \\
\hline & 083 & Niat individu dan orang tua pada bidang voli & Niat & 0.85 & 0.15 \\
\hline \multirow[t]{9}{*}{ Bulutangkis } & 001 & Fisik sehat & Fisik & 0.6 & 0.4 \\
\hline & 002 & Tidak memiliki cacat yang mengganggu kegiatan & Fisik & 0.55 & 0.45 \\
\hline & 026 & $\begin{array}{l}\text { Mampu melakukan passing, servis dan smashing dengan } \\
\text { shuttle sock }\end{array}$ & Kemampuan & 0.75 & 0.25 \\
\hline & 027 & Memiliki peralatan bulu tangkis (raket dan kok) & Kemampuan & 0.65 & 0.35 \\
\hline & 006 & Mampu meluangkan waktu sesuai ketentuan & Kemampuan & 0.55 & 0.45 \\
\hline & 007 & Mampu meluangkan waktu diluar ketentuan & Kemampuan & 0.55 & 0.45 \\
\hline & 057 & Mengetahui program bulu tangkis beserta kegiatannya & Pengetahuan & 0.6 & 0.4 \\
\hline & 058 & Mengetahui resiko dan manfaat bulu tangkis & Pengetahuan & 0.6 & 0.4 \\
\hline & 084 & Niat individu dan orang tua pada bidang bulu tangkis & Niat & 0.85 & 0.15 \\
\hline \multirow[t]{10}{*}{ Futsal } & 001 & Fisik sehat & Fisik & 0.6 & 0.4 \\
\hline & 002 & Tidak memiliki cacat yang mengganggu kegiatan & Fisik & 0.55 & 0.45 \\
\hline & 028 & Mampu melakukan dribbling, shooting dan merebut bola & Kemampuan & 0.75 & 0.25 \\
\hline & 029 & Memiliki peralatan futsal (sepatu futsal) & Kemampuan & 0.65 & 0.35 \\
\hline & 009 & Mampu bekerja dengan tim & kemampuan & 0.5 & 0.3 \\
\hline & 006 & Mampu meluangkan waktu sesuai ketentuan & Kemampuan & 0.55 & 0.45 \\
\hline & 007 & Mampu meluangkan waktu diluar ketentuan & Kemampuan & 0.55 & 0.45 \\
\hline & 059 & Mengetahui program futsal beserta kegiatannya & Pengetahuan & 0.6 & 0.4 \\
\hline & 060 & Mengetahui resiko dan manfaat futsal & Pengetahuan & 0.6 & 0.4 \\
\hline & 085 & Niat individu dan orang tua pada futsal & Niat & 0.85 & 0.15 \\
\hline \multirow[t]{9}{*}{ PALA } & 001 & Fisik sehat & Fisik & 0.6 & 0.4 \\
\hline & 010 & Mental Kuat & Kemampuan & 0.6 & 0.4 \\
\hline & 030 & Memiliki kecintaan tinggi terhadap alam & Kemampuan & 0.65 & 0.35 \\
\hline & 031 & Mampu menyesuaikan dengan lingkungan alam & Kemampuan & 0.65 & 0.35 \\
\hline & 006 & Mampu meluangkan waktu sesuai ketentuan & Kemampuan & 0.55 & 0.45 \\
\hline & 007 & Mampu meluangkan waktu diluar ketentuan & Kemampuan & 0.55 & 0.45 \\
\hline & 061 & Mengetahui program Pala beserta kegiatannya & Pengetahuan & 0.8 & 0.2 \\
\hline & 062 & Mengetahui resiko dan manfaat pala & Pengetahuan & 0.85 & 0.15 \\
\hline & 086 & Niat individu dan orang tua pada bidang pala & Niat & 0.95 & 0.05 \\
\hline \multirow[t]{9}{*}{ PMR } & 001 & Fisik sehat & Fisik & 0.6 & 0.4 \\
\hline & 032 & Memiliki kemauan tinggi menjadi anggota PMR & Kemampuan & 0.75 & 0.25 \\
\hline & 033 & $\begin{array}{l}\text { Mampu mengikuti pendidikan dan pelatihan sesuai } \\
\text { prosedur PMR }\end{array}$ & Kemampuan & 0.75 & 0.25 \\
\hline & 034 & Mampu melaksanakan tugas ke PMR.an & Kemampuan & 0.8 & 0.2 \\
\hline & 006 & Mampu meluangkan waktu sesuai ketentuan & Kemampuan & 0.6 & 0.4 \\
\hline & 007 & Mampu meluangkan waktu diluar ketentuan & Kemampuan & 0.6 & 0.4 \\
\hline & 063 & Mengetahui program PMR beserta kegiatannya & Pengetahuan & 0.65 & 0.35 \\
\hline & 064 & Mengetahui resiko dan manfaat PMR & Pengetahuan & 0.65 & 0.35 \\
\hline & 087 & Niat individu dan orang tua pada bidang PMR & Niat & 0.85 & 0.15 \\
\hline
\end{tabular}




\begin{tabular}{|c|c|c|c|c|c|}
\hline Ekstrakurikuler & Kode & Nama Variabel & Parameter & MB & MD \\
\hline \multirow[t]{8}{*}{ Paduan Suara } & 035 & $\begin{array}{l}\text { Mampu mengatur pernafasan dan intonasi suara dengan } \\
\text { baik }\end{array}$ & Kemampuan & 0.7 & 0.3 \\
\hline & 036 & Mampu menghafal lagu sesuai ketentuan & Kemampuan & 0.65 & 0.35 \\
\hline & 037 & Mampu menjaga konsumsi makanan sesuai anjuran & Kemampuan & 0.75 & 0.25 \\
\hline & 006 & Mampu meluangkan waktu sesuai ketentuan & Kemampuan & 0.55 & 0.45 \\
\hline & 007 & Mampu meluangkan waktu diluar ketentuan & Kemampuan & 0.55 & 0.45 \\
\hline & 065 & Mengetahui program padus beserta kegiatannya & Pengetahuan & 0.6 & 0.4 \\
\hline & 066 & Mengetahui resiko dan manfaat padus & Pengetahuan & 0.6 & 0.4 \\
\hline & 088 & Niat individu dan orang tua pada bidang padus & Niat & 0.85 & 0.15 \\
\hline \multirow[t]{11}{*}{ Pramuka } & 001 & Fisik sehat & Fisik & 0.55 & 0.45 \\
\hline & 010 & Mental kuat & Kemampuan & 0.55 & 0.45 \\
\hline & 011 & Ramah dan tegas & Kemampuan & 0.55 & 0.45 \\
\hline & 012 & Dapat dipercaya dan tanggung jawab & Kemampuan & 0.55 & 0.45 \\
\hline & 013 & Mampu kegiatan di bawah terik matahari & Kemampuan & 0.6 & 0.4 \\
\hline & 014 & Melakukan PBB & Kemampuan & 0.6 & 0.4 \\
\hline & 006 & Mampu meluangkan waktu sesuai ketentuan & Kemampuan & 0.55 & 0.45 \\
\hline & 007 & Mampu meluangkan waktu diluar ketentuan & Kemampuan & 0.55 & 0.45 \\
\hline & 067 & Mengetahui program Pramuka beserta kegiatannya & Pengetahuan & 0.6 & 0.4 \\
\hline & 068 & Mengetahui resiko dan manfaat Pramuka & Pengetahuan & 0.6 & 0.4 \\
\hline & 089 & Niat individu dan orang tua pada bidang Pramuka & Niat & 0.8 & 0.2 \\
\hline \multirow[t]{12}{*}{ PKS } & 001 & Fisik sehat & Fisik & 0.6 & 0.4 \\
\hline & 002 & Tidak memiliki cacat yang mengganggu kegiatan & Fisik & 0.6 & 0.4 \\
\hline & 010 & Mental kuat & Kemampuan & 0.55 & 0.45 \\
\hline & 011 & Ramah dan tegas & Kemampuan & 0.55 & 0.45 \\
\hline & 012 & Dapat dipercaya dan tanggung jawab & Kemampuan & 0.55 & 0.45 \\
\hline & 013 & Mampu kegiatan di bawah terik matahari & Kemampuan & 0.6 & 0.4 \\
\hline & 014 & Mampu Melakukan PBB & Kemampuan & 0.55 & 0.45 \\
\hline & 006 & Mampu meluangkan waktu sesuai ketentuan & Kemampuan & 0.6 & 0.4 \\
\hline & 007 & Mampu meluangkan waktu diluar ketentuan & Kemampuan & 0.6 & 0.4 \\
\hline & 069 & Mengetahui program PKS beserta kegiatannya & Pengetahuan & 0.6 & 0.4 \\
\hline & 070 & Mengetahui resiko dan manfaat PKS & Pengetahuan & 0.6 & 0.4 \\
\hline & 090 & Niat individu dan orang tua pada bidang PKS & Niat & 0.8 & 0.2 \\
\hline \multirow[t]{13}{*}{ Paskibraka } & 001 & Fisik sehat & Fisik & 0.6 & 0.4 \\
\hline & 002 & Tidak memiliki cacat yang mengganggu kegiatan & Fisik & 0.55 & 0.45 \\
\hline & 003 & Tinggi diatas $165 \mathrm{~cm}$ & Fisik & 0.6 & 0.4 \\
\hline & 004 & Berat Ideal & Fisik & 0.55 & 0.45 \\
\hline & 005 & Postur tegap & Fisik & 0.55 & 0.45 \\
\hline & 010 & Mental kuat & Kemampuan & 0.55 & 0.45 \\
\hline & 013 & Mampu kegiatan di bawah terik matahari & Kemampuan & 0.6 & 0.4 \\
\hline & 014 & Mampu melakukan PBB & Kemampuan & 0.75 & 0.25 \\
\hline & 006 & Mampu meluangkan waktu sesuai ketentuan & Kemampuan & 0.55 & 0.45 \\
\hline & 007 & Mampu meluangkan waktu diluar ketentuan & Kemampuan & 0.55 & 0.45 \\
\hline & 071 & Mengetahui program Paskib beserta kegiatannya & Pengetahuan & 0.6 & 0.4 \\
\hline & 072 & Mengetahui resiko dan manfaat Paskib & Pengetahuan & 0.6 & 0.4 \\
\hline & 091 & Niat individu dan orang tua pada bidang Paskib & Niat & 0.85 & 0.15 \\
\hline \multirow[t]{5}{*}{ MTQ } & 038 & Fasih dalam hal tajwid dan baca Al-qur'an & Kemampuan & 0.75 & 0.25 \\
\hline & 035 & $\begin{array}{l}\text { Mampu mengatur pernafasan dan intonasi suara dengan } \\
\text { baik }\end{array}$ & Kemampuan & 0.7 & 0.3 \\
\hline & 039 & Mengetahui pola dan ritme dalam MTQ & Kemampuan & 0.7 & 0.3 \\
\hline & 006 & Mampu meluangkan waktu sesuai ketentuan & Kemampuan & 0.6 & 0.4 \\
\hline & 073 & Mengetahui program MTQ beserta kegiatannya & Pengetahuan & 0.6 & 0.4 \\
\hline
\end{tabular}




\begin{tabular}{|c|c|c|c|c|c|}
\hline Ekstrakurikuler & Kode & Nama Variabel & Parameter & MB & MD \\
\hline & 074 & Mengetahui resiko dan manfaat MTQ & Pengetahuan & 0.6 & 0.4 \\
\hline & 092 & Niat individu dan orang tua pada bidang MTQ & Niat & 0.85 & 0.15 \\
\hline \multirow[t]{7}{*}{ KIR } & 040 & Memahami tata penulisan karya ilmiah sesuai ketentuan & Kemampuan & 0.8 & 0.2 \\
\hline & 041 & Memiliki 1 atau lebih bidang keilmuan yang dikuasai & Kemampuan & 0.6 & 0.4 \\
\hline & 042 & Bersedia melakukan penelitian sesuai dengan judul & Kemampuan & 0.7 & 0.3 \\
\hline & 006 & Mampu meluangkan waktu sesuai ketentuan & Kemampuan & 0.6 & 0.4 \\
\hline & 075 & Mengetahui program KIR beserta kegiatannya & Pengetahuan & 0.6 & 0.4 \\
\hline & 076 & Mengetahui resiko dan manfaat KIR & Pengetahuan & 0.6 & 0.4 \\
\hline & 093 & Niat individu dan orang tua pada bidang KIR & Niat & 0.85 & 0.15 \\
\hline
\end{tabular}

Data kasus lama kegiatan ekstrakurikuler dibandingkan dengan data siswa di tiap variabel untuk mengetahui kecocokan minat dan bakatnya. Setiap pilihan dihitung nilai kepastian siswa dalam mengikuti kegiatan ekstrakurikuler. Variabel data siswa yang akan dicocokkan ada pada Tabel 2.

TABEL 2

DATA SISWA

\begin{tabular}{|c|c|c|}
\hline No. & Parameter & Variabel \\
\hline 1 & Fisik & $\begin{array}{l}\text { 1. Tinggi badan, } \\
\text { 2. Tidak menderita cacat yang mengganggu setiap } \\
\text { kegiatan ekstrakurikuler } \\
\text { 3. Fisik sehat } \\
\text { 4. Postur tegap } \\
\text { 5. Berat ideal }\end{array}$ \\
\hline 2 & Kemampuan & $\begin{array}{l}\text { 1. Kemampuan yang diandalkan } \\
\text { 2. Kemampuan dalam mengikuti kegiatan sesuai } \\
\text { ketentuan } \\
\text { 3. Kemampuan mengikuti kegiatan diluar } \\
\text { ketentuan }\end{array}$ \\
\hline 3 & Pemahaman & $\begin{array}{l}\text { 1. Memahami program ekstrakurikuler } \\
\text { 2. Mengetahui manfaat, dan resiko setiap kegiatan } \\
\text { ekstrakurikuler }\end{array}$ \\
\hline 4 & Niat & 1. Niat individu dan orang tua \\
\hline
\end{tabular}

\section{Perhitungan Metode CBR dan $C F$}

CBR mempunyai basic knowledge atau pengetahuan dasar yang bisa dibandingkan dengan kasus baru [6]. Ada 4 fase dalam metode CBR yaitu retrieve (pengguna memasukkan kasus baru selanjutnya sistem akan mencari kesamaan pada kasus yang sudah tersimpan sebelumnya dengan membandingkan berdasarkan perhitungan $\mathrm{CF}$ ), reuse (ketika perhitungan selesai akan muncul nilai kepastian dan memunculkan informasi yang memiliki kemiripan untuk dievaluasi kesesuaiannya), revise (sistem merevisi kasus lama apakah informasi yang dihasilkan sesuai dengan yang dibutuhkan), dan retain (sistem menambahkan kasus baru ke case base berdasarkan perhitungan yang dilakukan) [7] [8].

CF dibutuhkan untuk menghitung nilai persentase dengan kepastian kasus yang dimasukkan ke dalam sistem (Batubara, 2018). Algoritma ini pertama kali diperkenalkan pada tahun 1975 oleh Shortliffe Buchanan yang sedang mengembangkan sistem pakar MYCIN. CF mengakomodasi nilai yang tidak pasti dari pakar untuk mengambil sebuah keputusan. Terdapat dua macam faktor kepastian yang dipakai yakni faktor kepastian yang didapatkan dari pakar dengan aturan dan faktor kepastian yang diisikan oleh pengguna. Faktor yang diisikan oleh pakar berarti tingkat kepercayaan pakar dalam suatu kondisi. Sedangkan faktor dari pengguna berarti tingkat kepercayaan terhadap masing-masing kondisi yang dialami. Pakar dalam penentuan keputusan terkadang mengungkapkan hal yang tidak pasti seperti "kemungkinan besar" dan "hampir pasti" [9]. Derajat nilai kepastian dan ketidakpastian akan dijumlahkan yang selanjutnya menghasilkan nilai satu [10].

Perhitungan dengan CF memiliki dua rule yang digunakan untuk mencari tahu kondisi sebagai berikut:

a. $\quad$ Metode CF secara umum [9]

$C F(H, E)=M B(H, E)-M D(H, E)$

Keterangan:

CF (H,E): faktor kepastian 
MB (H,E): nilai kepercayaan hipotesis $(\mathrm{H})$ terhadap evidence $(\mathrm{E})$

MD (H,E): nilai ketidakpercayaan hipotesis $(\mathrm{H})$ terhadap evidence $(\mathrm{E})$

Tabel 3 adalah hasil interpretasi penilaian metode CF:

TABEL 3

INTERPRETASI PENILAIAN CF [11]

\begin{tabular}{ll}
\hline \multicolumn{1}{c}{ Nilai Kepastian } & \multicolumn{1}{c}{ MB-MD $=\mathbf{C F}$} \\
\hline Pasti (Tidak) & -1 \\
\hline Hampir pasti (Tidak) & $-0,99--0,8$ \\
\hline Kemungkinan besar (Tidak) & $-0,79--0,4$ \\
\hline Kemungkinan (Tidak) & $-0,59--0,4$ \\
\hline Tidak mengetahui & $-0,39-0,39$ \\
\hline Kemungkinan (Ya) & $0,4-0,59$ \\
\hline Kemungkinan besar (Ya) & $0,6-0,79$ \\
\hline Hampir pasti (Ya) & $0,79-0,99$ \\
\hline Pasti (Ya) & 1 \\
\hline
\end{tabular}

b. Metode $\mathrm{CF}$ dengan banyak gejala [12]:

$C F(H, E)=C F(E) X C F($ rule $)$

Jika ada kesimpulan yang mirip lebih dari satu gejala akan dihitung dengan rumus sebagai berikut:

CFcombine $(C F 1, C F 2)=C F 1+C F 2 x(1-C F 1)$

Selanjutnya mencari nilai $\mathrm{CF}$ yang terakhir dengan rumus sebagai berikut:

Rasio Kepercayaan $=$ CFcombine $x 100 \%$

\section{Pengembangan Sistem}

Tahapan pengembangan sistem adalah sebagai berikut:

1. Menganalisis kebutuhan sistem yang akan diterapkan. Komponen SPK terdiri dari 4 komponen yaitu data management, model management, communication / dialog management, knowledge management didapatkan dari studi literatur dan informasi dari pakar.

2. Sistem akan didesain untuk memudahkan implementasi ke dalam bahasa pemrograman. Hasilnya adalah desain alur dengan Unit Modeling Language (UML) dan basis data.

3. Menerjemahkan desain menjadi sebuah sistem yang berbasis web PHP. Hasilnya adalah sebuah sistem berbasis web yang selanjutnya disebut Sistem Penentuan Ekstrakurikuler Siswa (SPES) untuk memudahkan penyebutan.

\section{E. Performance Metrics}

Performance metrics dilakukan dengan menyebarkan kuesioner online ke sampel siswa MAN 1 Lamongan untuk mencari tahu informasi minat dan bakat dari data keanggotaan ekstrakurikuler. Sampel ditentukan dari populasi kelas X dan X1 MAN 1 Lamongan yang berjumlah 720 siswa dengan perhitungan Slovin. Jika margin kesalahan yang dikehendaki adalah $13 \%$ maka sampel yang diperlukan adalah sebagai berikut [17]:

$$
\begin{aligned}
& n=\frac{\mathrm{N}}{1+\mathrm{N} e^{2}} \\
& n=\frac{720}{1+720\left(13 \%^{2}\right)} \\
& n=54,6
\end{aligned}
$$

Sampel dibulatkan menjadi 55 yang selanjutnya dibagi ke 17 ekstrakurikuler untuk mendapatkan hasil yang merata. Hasilnya adalah 3,23 dan akan dibulatkan menjadi 4 sampel per ekstrakurikuler. Data yang diperoleh akan diolah dengan SPES untuk mengetahui kecocokan rekomendasi. Hasil rekomendasi akan diuji dengan confusion matrix seperti pada Tabel 4 untuk mencari tahu tingkat precision, recall dan accuracy [18]. 
TABEL 4

CONFUSION MATRIX

\begin{tabular}{llll}
\cline { 3 - 3 } & & \multicolumn{2}{c}{ Nilai Sebenarnya } \\
\cline { 2 - 3 } Nilai Prediksi & True & True Positive $(T P)$ & Truative \\
\cline { 2 - 3 } & False & False Positive & False Negative $(T N)$ \\
\hline
\end{tabular}

Perhitungan precision, recall, dan accuracy adalah sebagai berikut

$$
\begin{aligned}
& \text { Precision }=\frac{T P}{T P+F P} \times 100 \% \\
& \text { Recall }=\frac{T P}{T P+F N} \times 100 \% \\
& \text { Accuracy }=\frac{\sum \text { match }}{\sum t p} \times 100 \%
\end{aligned}
$$

Pengujian confusion matrix dilakukan sebanyak tiga kali berdasarkan rekomendasi sistem dengan kejadian sesungguhnya, rekomendasi pakar dengan rekomendasi sistem, kejadian sesungguhnya dengan rekomendasi pakar. Selanjutnya mencari nilai akhir dengan mencari nilai rata-rata dari precision, recall, dan acuracy berdasarkan tiga pengujian sebelumnya. Hasilnya akan dikategorikan rendah (nilai rata-rata $0-33,33 \%)$, sedang $(33,34 \%-66,66 \%)$, dan tinggi $(66,67 \%-100 \%)$ [5].

\section{HASIL DAN PEMBAHASAN}

\section{A. Analisis Kebutuhan}

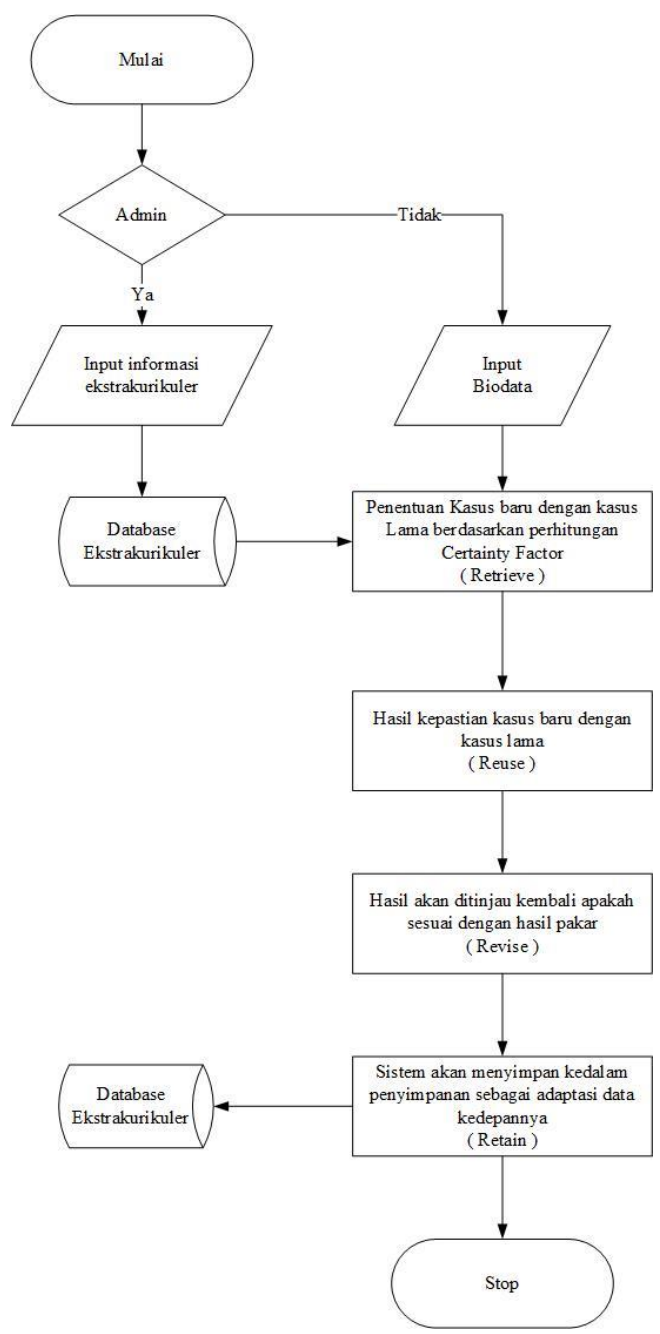

Gambar 3. Flowchart Rekomendasi 
Gambar 3 merupakan flowchart rekomendasi sistem yang akan berjalan. Penjelasannya adalah sebagai berikut:

1. Admin membuka web browser dan login ke dalam sistem

2. Jika login admin disetujui maka akan diberikan akses untuk menambah / menghapus / mengubah data ekstrakurikuler untuk mengevaluasi hasil

3. Jika belum memiliki user admin, maka diharuskan untuk memasukkan biodata

4. Tahapan retrieve: sistem memutuskan nilai kepastian kasus baru dengan kasus lama menggunakan CF. Kepastian ditentukan dari parameter yang didapat dari masukan $u$ ser.

5. Tahapan reuse: sistem memberikan hasil berupa nilai kepastian terbesar dari setiap kegiatan ekstrakurikuler

6. Tahapan revise: admin bisa merevisi hasil jika terdapat siswa yang lebih / kurang sesuai dengan kegiatan ekstrakurikuler yang sudah berjalan. Revisi yang dilakukan adalah memperbaiki parameter yang kurang signifikan atau bobot yang diberikan masih kurang / lebih berdasarkan hasil yang didapat untuk meningkatkan akurasi sistem

7. Tahapan retain: sistem menyimpan revisi yang dilakukan untuk memperbarui parameter kegiatan ekstrakurikuler.

\section{B. Implementasi SPK}

Sistem penentuan ekstrakurikuler berdasarkan minat dan bakat siswa MAN 1 Lamongan diberi nama SPES atau Sistem Penentuan Ekstrakurikuler Siswa. Penentuan keputusan didasarkan pengetahuan dari pakar dalam hal ini adalah pembina ekstrakurikuler. Berdasarkan dari Gambar 1 tentang komponen dalam SPK maka akan dibuat alur SPK yang tersusun dari empat komponen utama yang ditunjukkan pada Gambar 4.

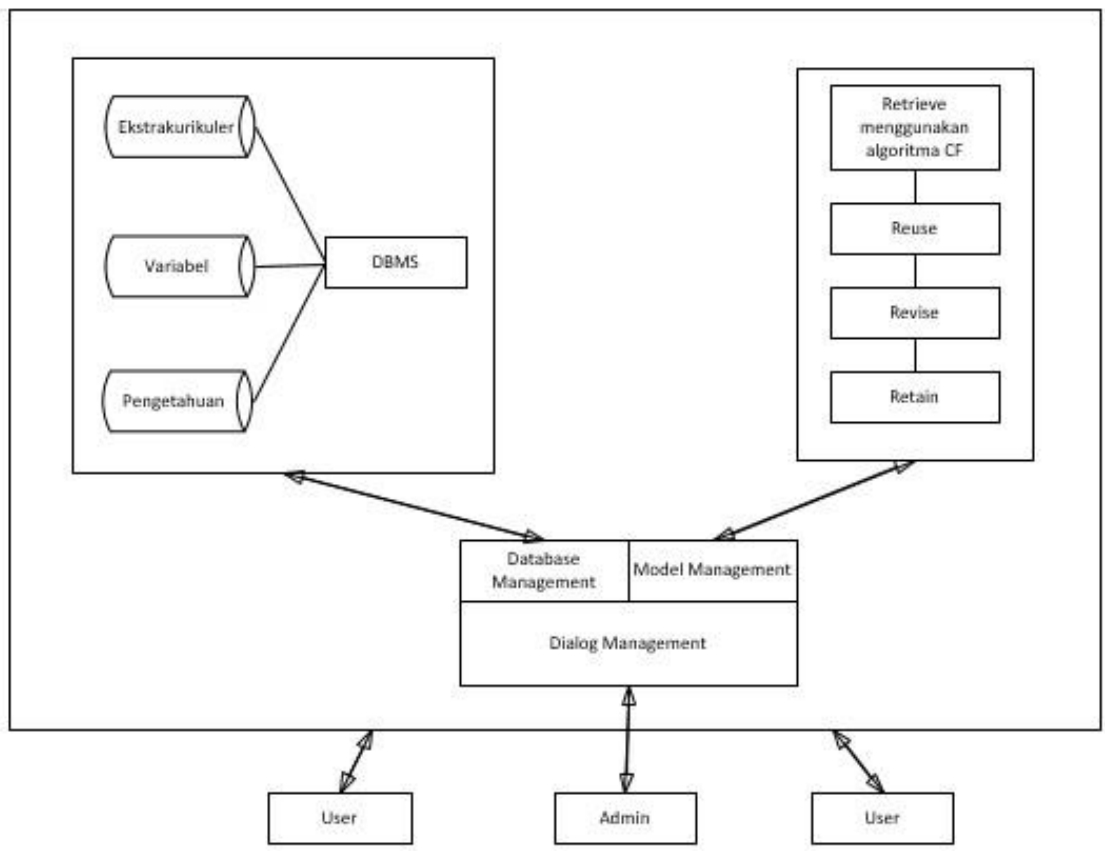

Gambar 4. Desain SPK

Penjelasannya adalah sebagai berikut:

1. User: pengguna yang mengakses SPES namun hanya bisa melihat dan membuat analisis kegiatan ekstrakurikuler

2. Admin: pengguna yang mengelola data SPES mulai dari manajemen data, pengetahuan dan model informasi.

3. Data Management: terdiri dari data ekstrakurikuler, data variabel dan data pengetahuan yang disimpan dalam database

4. Model Management: data diolah menjadi sumber informasi penentuan keputusan. CBR dan CF digunakan pada tahapan ini yang terdiri dari empat langkah yaitu:

a. Retrieve: data variabel yang sudah berisi pengetahuan ditampilkan dan dipilih oleh user. Hasil pilihan user dihitung dengan $\mathrm{CF}$

b. Reuse: hasil CF dikalikan $100 \%$ dan nilai yang terbesar dijadikan keputusan rekomendasi kegiatan ekstrakurikuler 
c. Revise: masukan yang dipilih oleh user akan ditampilkan dan admin mengevaluasi apakah pengetahuan yang diberikan sesuai

d. Retain: hasil perubahan disimpan dan dijadikan pengetahuan baru untuk rekomendasi berikutnya

5. Dialog Management: tampilan komunikasi admin dengan SPK untuk mengelola data

\section{Perhitungan dengan $C B R$ dan $C F$}

Perhitungan dengan metode CBR dan CF akan diterapkan untuk menentukan rekomendasi ekstrakurikuler siswa MAN 1 Lamongan berdasarkan minat dan bakat. Sebagai contoh hasil perhitungan rekomendasi kegiatan ekstrakurikuler dari salah satu sampel siswa akan ditampilkan sebagai berikut:

\section{Retrieve}

Data kasus baru yang memiliki kemiripan akan dihitung nilai kepastiannya. Siswa memilih variabel yang sesuai dengan bakatnya dan fokus ke salah satu minat yang dipilih. Siswa juga mengisi CF untuk variabel yang sudah dipilih. CF kegiatan ekstrakurikuler hasil pengurangan dari MB - MD seperti pada Rumus 1 dan Tabel 5 adalah penjelasan perbandingan data kasus baru dan kasus lama.

TABEL 5

DATA KASUS BARU DENGAN KASUS LAMA

\begin{tabular}{llll}
\hline \multicolumn{1}{c}{ Nama variabel } & Nilai CF \\
\hline Fisik sehat & 1
\end{tabular}

Dari Tabel 5 dapat ditarik kesimpulan yakni kesamaan data kasus baru dari siswa baru dan ekstrakurikuler teater dengan kode variabel 010, 008, 006, 007, 015, 043, 044, dan 077. Selanjutnya menentukan nilai CF total antara data kasus lama dari pakar dengan data kasus baru dari siswa dengan Rumus 2.

$\mathrm{CF}($ Teater, 010) $=\mathrm{CF}(010) \times \mathrm{CF}($ rule $)$

$$
\begin{aligned}
& =0,8 \times 0,2 \\
& =0,16
\end{aligned}
$$

Kode variabel 010 memiliki nilai CF 0,16. Selanjutnya mencari nilai CF dari variabel yang ditampilkan di Tabel 6.

TABEL 6

DATA CF USER (TEATER)

\begin{tabular}{cccc}
\hline Kode & CF User & CF rule & CF total \\
\hline 010 & 0,8 & 0,2 & 0,16 \\
\hline 008 & 0,8 & 0,2 & 0,16 \\
\hline 006 & 0,8 & 0,1 & 0,08 \\
\hline 007 & 0,8 & 0,1 & 0,08 \\
\hline 015 & 0,8 & 0,5 & 0,4 \\
\hline 043 & 1 & 0,2 & 0,2 \\
\hline 044 & 1 & 0,2 & 0,2 \\
\hline 077 & 1 & 0,7 & 0,7
\end{tabular}

Nilai CF combine dicari dengan mengkombinasikan nilai CF total bertahap sesuai dengan Rumus 3

$\mathrm{CF}$ combine $(\mathrm{CF} 1, \mathrm{CF} 2) \quad=\mathrm{CF} 1+\mathrm{CF} 2 \times(1-\mathrm{CF} 1)$ 


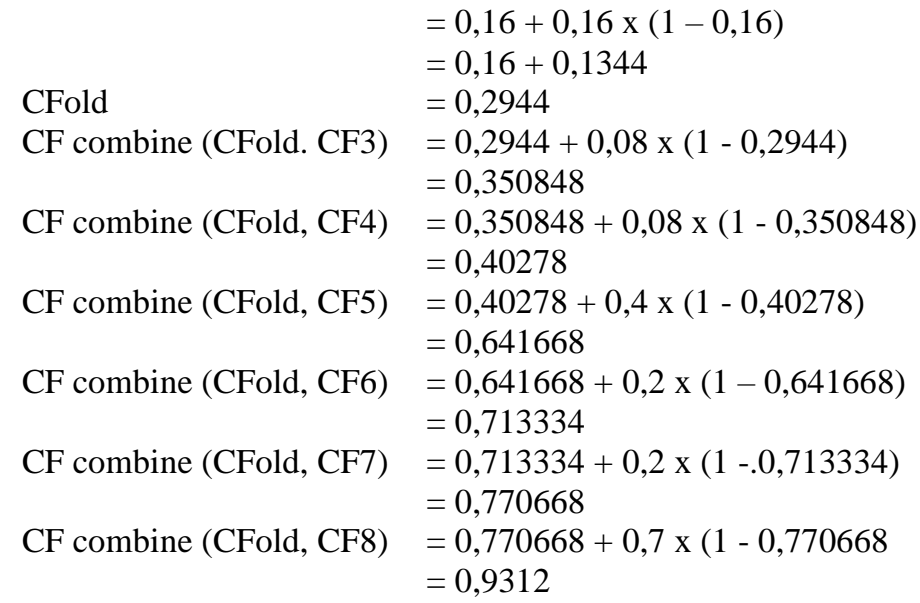

Kecocokan variabel ditentukan sehingga didapatkan nilai prioritas tertinggi sebagai rekomendasi ekstrakurikuler sesuai dengan perhitungan CF. Hasilnya nilai CF tertinggi adalah ekstrakurikuler teater $(0,9312)$. Nilai CF dari ekstrakurikuler lain adalah banjari $(0,08)$, band $(0,6218)$, gambus $(0,08)$, drumband $(0,4073)$, basket $(0,3906)$, voli $(0,3906)$, bulu tangkis $(0,3906)$, futsal $(0,3906)$, pala $(0,4312)$, PMR $(0,4355)$, padus $(0,1536)$, pramuka $(0,2992)$, PKS $(0,5845)$, paskib $(0,4393)$, MTQ $(0,16)$, dan KIR $(0,16)$.

2. Reuse

Hasil CF dihitung menggunakan Rumus 4 untuk mencari tahu rasio kepastiannya. Hasilnya adalah ekstrakurikuler teater mendapat $93,12 \%$. Nilai dari ekstrakurikuler lain adalah banjari $8 \%$, band $62,18 \%$, gambus $8 \%$, drumband $40,73 \%$, basket $39,06 \%$, voli 39,06 \%, bulu tangkis 39,06 \%, futsal 39,06 \%, pala 43,12 \%, PMR 43,55 \%, padus $15,36 \%$, pramuka 29,92\%, PKS 58,45\%, paskib 43,93\%, MTQ $16 \%$, dan KIR $16 \%$.

3. Revise

Proses ini mengevaluasi masukan dari user dengan nilai CF yang diberikan. Pakar merevisi jika terdapat siswa yang mempunyai minat dan bakat yang diinginkan pakar tetapi mempunyai nilai yang rendah. Revisi nilai apabila terjadi kesalahan seperti siswa yang tidak percaya diri dalam mengisikan nilai kepastian atau bobot variabel dari pakar harus diperbaiki lagi agar lebih optimal.

4. Retain

Hasil rekomendasi dari sistem diketahui berdasarkan masukan dari user. Jika pakar mengubah pengetahuan di fase revise maka perubahan langsung diterapkan sebagai pengetahuan baru.

\section{Desain Sistem dan Basis Data}

Terdapat dua aktor yakni user biasa yang dipakai siswa dan user admin yang dipakai pengelola SPES seperti yang ditunjukkan Gambar 5. 


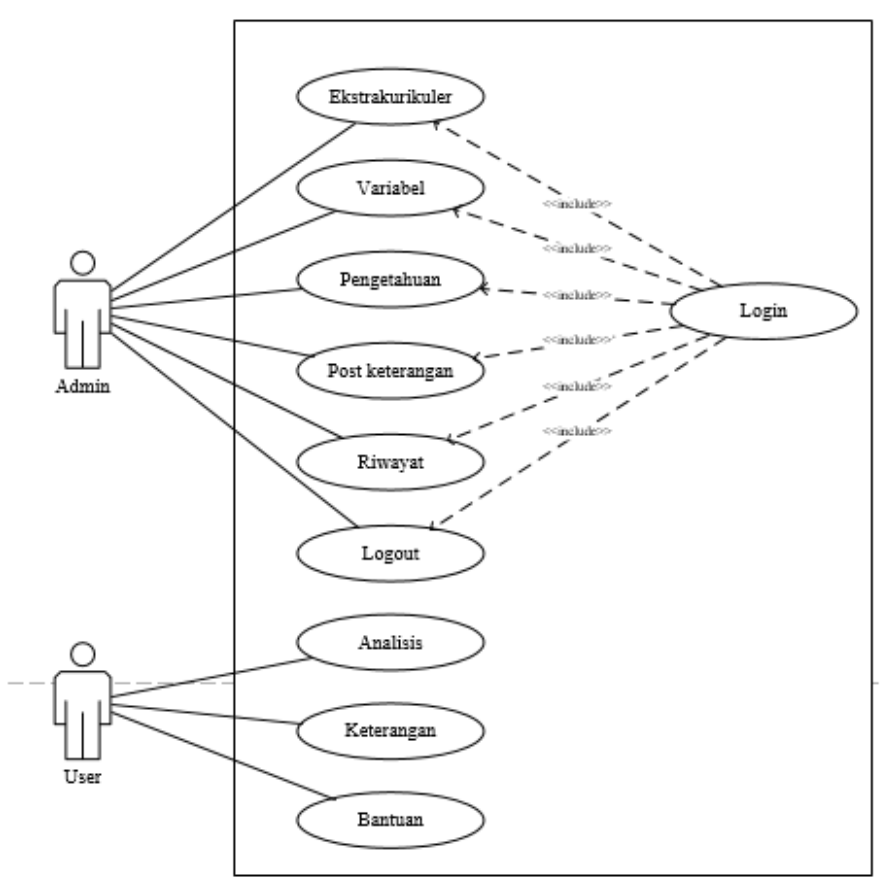

Gambar 5. Use Case Diagram

Desain basis data di Gambar 6 terdiri dari 2 tabel master yaitu tabel ekstrakurikuler yang berisi detail kegiatan ekstrakurikuler dan tabel variabel yang berisi kriteria parameter setiap kegiatan ekstrakurikuler. Tabel lain berfungsi untuk penyimpanan pengetahuan dan menyimpan masukan dari user

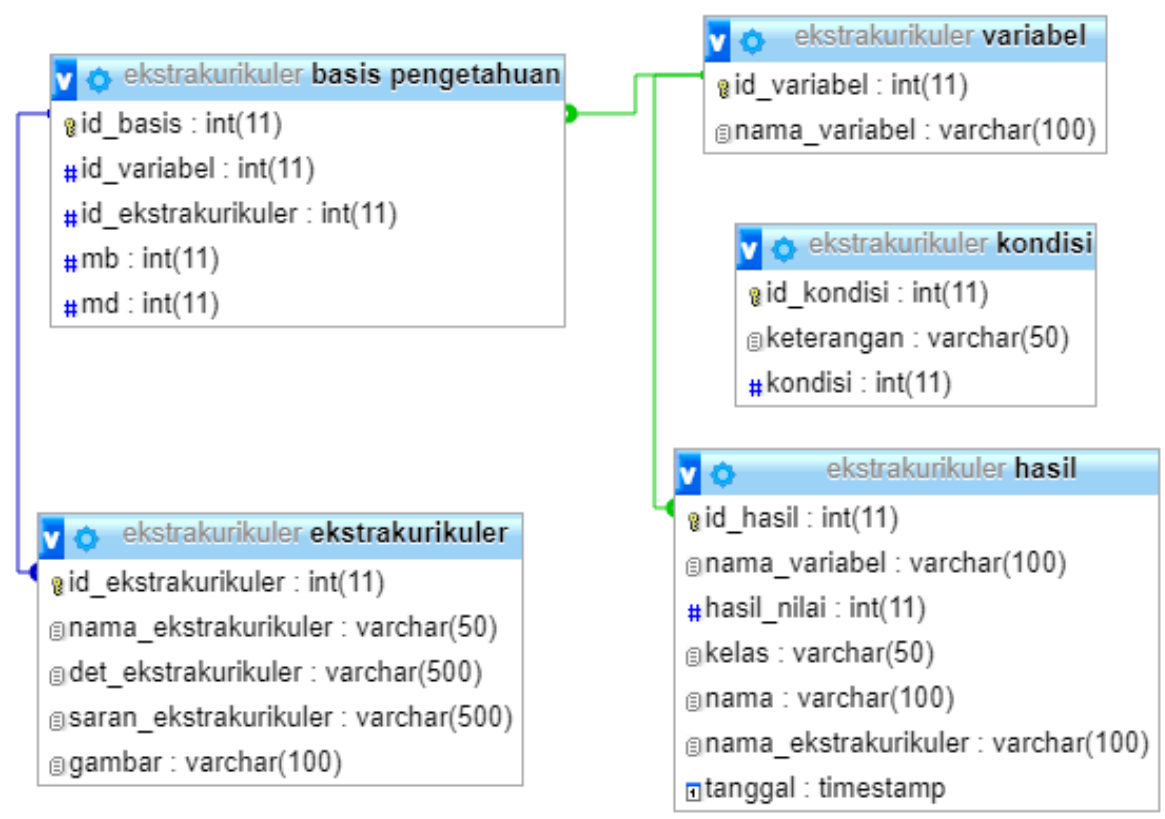

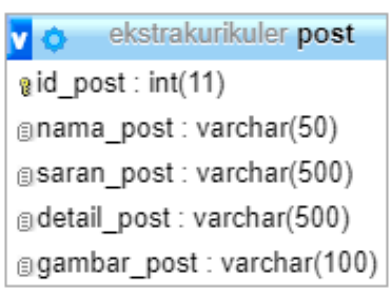

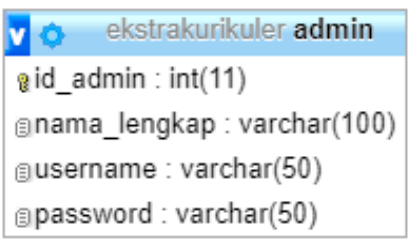

Gambar 6. Desain Basis Data 


\section{E. Hasil Pengembangan SPES}

Berikut adalah hasil dari pengembangan SPES. Gambar 7 tempat siswa memasukkan variabel dan kondisinya di halaman Analisis Ekstrakurikuler. Gambar 8 berisi daftar pengetahuan ekstrakurikuler yang ada di MAN 1 Lamongan.

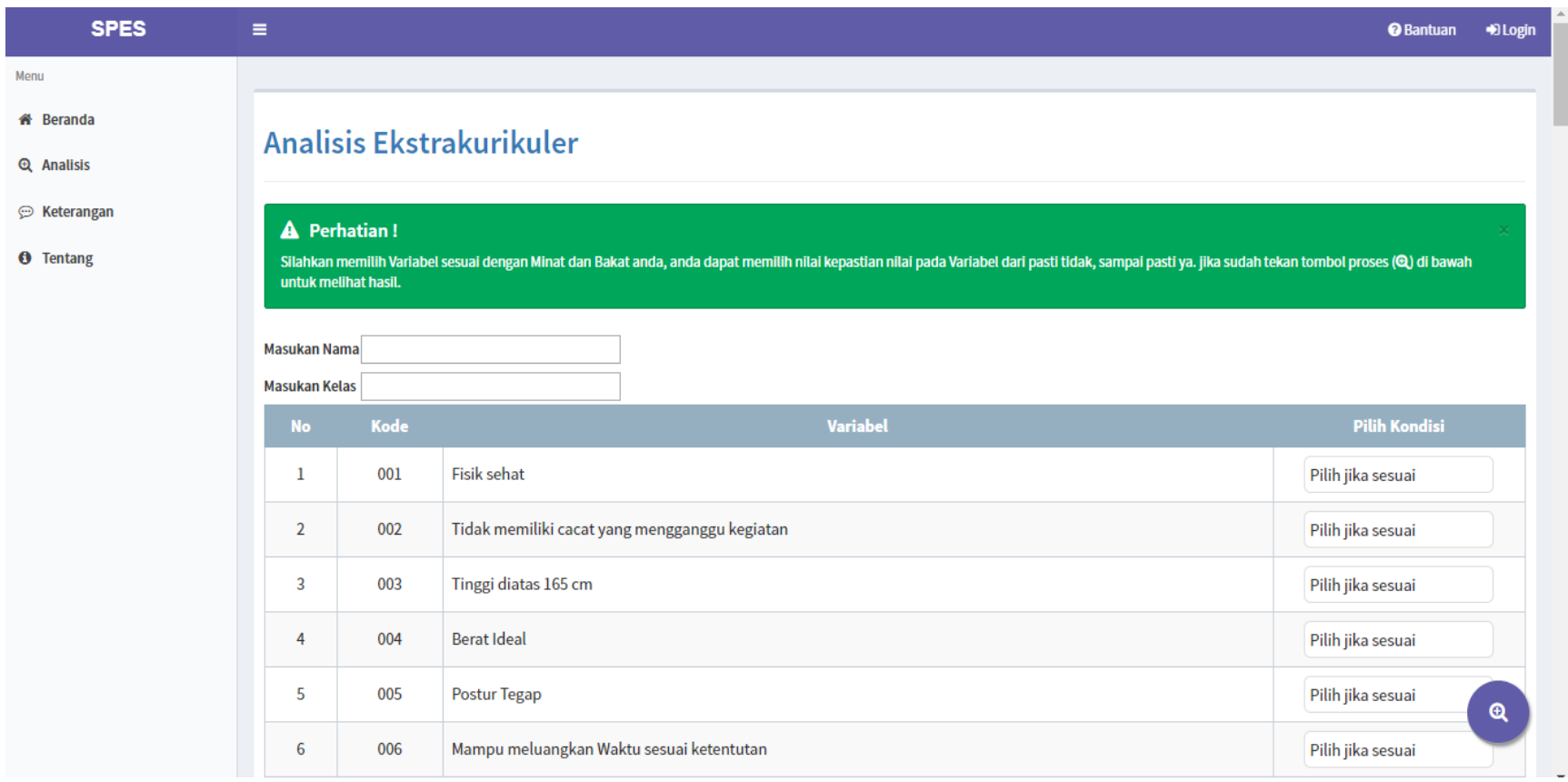

Gambar 7. Halaman Analisis Ekstrakurikuler

* Beranda

a Admin

[G Ubah Password

A. Ekstrakurikuler

Variabel

I Pengetahuan

G Post Keterangan

○ Riwayat

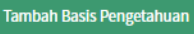

Ketik dan tekan cari..

No Penyakit Gejala

1 Teater Mental kuat

2 Teater Memiliki Kepercayaan diri tinggi

3 Teater

$4 \quad$ Teater

Mampu meluangkan waktu diluar ketentuan

5 Teater

Mampu berakting/memiliki imajinasi tinggi

6 Teater

Mengetahui progam teater beserta kegiatannya
MB

$0.6 \quad 0.4$

$\mathbb{Z}$ Ubah $\quad$ GHapus

$0.6 \quad 0.4$

$0.6 \quad 0.5$

$0.6 \quad 0.5$

$0.7 \quad 0.3$

$0.5 \quad 0.4$

Gambar 8. Halaman Pengetahuan 


\section{F. Performance Metrics}

Data yang digunakan untuk performance metrics ini adalah data dari kuesioner yang disebarkan ke sampel siswa MAN 1 Lamongan. Kuesioner disebarkan ke 68 siswa yang masing-masing ekstrakurikuler diwakili oleh 4 siswa sesuai dengan penjelasan di bagian Metode Penelitian. Jawaban kuesioner dihitung menggunakan Rumus 7, Rumus 8, dan Rumus 9 sehingga hasilnya sebagai berikut:

1. Rekomendasi sistem dengan kejadian sesungguhnya

Dilakukan untuk mencari tahu keberhasilan rekomendasi SPES dengan kejadian sesungguhnya saat kegiatan ekstrakurikuler sudah diikuti oleh siswa. Perhitungannya adalah sebagai berikut:

$$
\begin{aligned}
& \text { Precision }=\frac{65}{65+3} \times 100 \%=95,58 \% \\
& \text { Recall }=\frac{65}{65+0} \times 100 \%=100 \% \\
& \text { Accuracy }=\frac{65}{65+0+3+0} \times 100 \%=95,58 \%
\end{aligned}
$$

2. Rekomendasi sistem dengan rekomendasi pakar

Dilakukan untuk mencari tahu keberhasilan rekomendasi SPES dengan rekomendasi pakar pembina ekstrakurikuler. Perhitungannya adalah sebagai berikut:

$$
\begin{aligned}
& \text { Precision }=\frac{62}{62+5} \times 100 \%=92,53 \% \\
& \text { Recall }=\frac{62}{62+1} \times 100 \%=98,4 \% \\
& \text { Accuracy }=\frac{62+0}{62+0+5+1} \times 100 \%=91,17 \%
\end{aligned}
$$

3. Rekomendasi pakar dengan kejadian sesungguhnya

Dilakukan untuk mencari tahu keberhasilan pakar dalam merekomendasikan keputusan dengan kejadian sesungguhnya saat kegiatan ekstrakurikuler sudah diikuti oleh siswa. Perhitungannya adalah sebagai berikut:

$$
\begin{aligned}
& \text { Precision }=\frac{68}{68+0} \times 100 \%=100 \% \\
& \text { Recall }=\frac{68}{68+0} \times 100 \%=100 \% \\
& \text { Accuracy }=\frac{68}{68} \times 100 \%=100 \%
\end{aligned}
$$

Selanjutnya mencari nilai akhir dari precision, recall, dan accuracy dengan mencari nilai rata-rata sebagai berikut:

Precision akhir $=\frac{95,58+92,53+100}{3}=96,03 \%$

Recall akhir $=\frac{100+98,4+100}{3}=99,4 \%$

Accuracy akhir $=\frac{95,58+91,7+100}{3}=95,76 \%$

Dari hasil pengujian matriks-matriks performa yang dilakukan, hasil yang didapat tidak semua sempurna $100 \%$. Pada pengujian pertama antara sistem yang dibuat dengan kejadian nyata terdapat kendala pada pengujian presisi dan akurasi sistem, hal ini bisa berasal dari pemberian nilai MB dan MD yang perlu dilakukan penelitian kembali, selanjutnya hasil sistem dengan rekomendasi pakar mendapatkan kendala pada semua pengujian, hal ini berarti sistem yang dibuat tidak $100 \%$ sesuai dengan hasil yang diharapkan oleh pakar, dan yang terakhir kejadian sebenarnya dengan rekomendasi pakar. Pada pengujian ini ketiga pengujian sudah sesuai dengan hasil yang diharapkan pakar yang artinya setiap variabel yang menjadi acuan sudah sesuai.

Kesimpulan dari ketiga pengujian di atas dapat disimpulkan bahwa dari setiap variabel yang diberikan oleh pakar sudah sesuai dengan kebutuhan dan hasil rekomendasi sistem yang dibangun namun dalam perhitungan secara kepastian masih terdapat beberapa kendala yang bisa berasal dari pemberian bobot pada setiap variabel kepastian yang diberikan

\section{SIMPULAN}

CBR dan CF berhasil diterapkan dalam penentuan kegiatan ekstrakurikuler siswa MAN 1 Lamongan berdasarkan minat dan bakat. Implementasinya adalah sebuah sistem yang diberi nama SPES dan dikembangkan berbasis web. SPES menggunakan tahapan dalam CBR yakni retrieve, reuse, revise, dan retain. Algoritma CF dipakai untuk menentukan kepastian di setiap variabel.

Hasil confusion matrix menunjukkan bahwa SPES mampu merekomendasikan ekstrakurikuler dengan baik dan ditunjukkan dengan nilai precision sebesar 96,03 \%. SPES juga mampu memberikan informasi positif dan menemukan 
kembali informasi dengan baik dan ditunjukkan dengan nilai recall sebesar 99,4 \%. Terakhir, SPES memiliki akurasi yang tinggi dalam memberikan rekomendasi berdasarkan keseluruhan data yang ditunjukkan dengan nilai accuracy sebesar $95,76 \%$

\section{UCAPAN TERIMA KASIH}

Ucapan terima kasih kepada seluruh pihak dari MAN 1 Lamongan yang telah membantu dan bersedia dijadikan sebagai tempat untuk penelitian ini.

\section{DAFTAR PUSTAKA}

[1] N. Yanti dan R. Adawiyah, "Pelaksanaan Kegiatan Ekstrakurikuler dalam Rangka Pengembangan Nilai-Nilai Karakter Siswa untuk Menjadi Warga Negara yang Baik di SMA KORPRI Banjarmasin.," Jurnal Pendidikan Kewarganegaraan, vol. 6, no. 11, 2016.

[2] Kementerian Pendidikan dan Kebudayaan, "Peraturan Menteri Pendidikan dan Kebudayaan Republik Indonesia No. 62 Tahun $2014 . "$ Jakarta, 2014.

[3] A. S. Anam, "Implementasi Metode CBR dan CF dalam Menentukan Ekstrakurikuler Siswa MAN 1 Lamongan Sesuai Minat dan Bakat," UIN Sunan Ampel Surabaya, 2020,

[4] MAN 1 Lamongan, "MAN 1 Lamongan," 2021. [Daring]. Tersedia pada: https://man1lamongan.sch.id/. [Diakses: 23-Sep-2021].

[5] K. Izzah, "Sistem Pendukung Keputusan Kelayakan Penerima Program Keluarga Harapan (PKH) Menggunakan Algoritma Analytic Network Process," UIN Sunan Ampel Surabaya, 2019.

[6] A. Y. Vandika dan A. Cucus, "Sistem Deteksi Awal Penyakit TBC dengan Metode CBR,” Jurnal Informatika, vol. 17, no. 2, hal. 54-60, 2017.

[7] J. Ismail, "Sistem Rekomendasi Topik Skripsi Menggunakan Metode Case Based Reasoning," JITTER, vol. IV, no. 3, hal. 174-183, 2018.

[8] S. Batubara, "Penerapan Metode Certainty Factor pada Sistem Pakar Diagnosa Penyakit Dalam," Khazanah Informatika: Jurnal Ilmu Komputer Dan Informatika, vol. 4, no. 2, hal. 90, 2018.

[9] D. Fauziah, H. Mubarok, dan N. I. Kurniati, “Sistem Pakar untuk Mendiagnosa Penyakit Persendian Menggunakan Metode Certainty Factor,” Jurnal Teknik Informatika dan Sistem Informasi, vol. 4, no. 1, 2018.

[10] N. Sunaryo, Y. Yuhandri, dan S. Sumijan, "Sistem Pakar Menggunakan Metode Certainty Factor dalam Identifikasi Pengembangan Minat dan Bakat Khusus pada Siswa," Jurnal Sistim Informasi Dan Teknologi, vol. 3, no. 2, hal. 48-55, 2021.

[11] N. A. Putri, "Expert System to Identify Student Personality using Certainty Factor Method in Supporting Teacher Approach," Journal of Information Technology and Computer Science (INTECOMS), vol. 1, no. 1, 2018.

[12] E. Rohadi, O. D. Triswidrananta, dan J. Ayu, "Sistem Pakar Pendeteksi Kerusakan Kamera DSLR dengan Metode Case Based Reasoning dan Certainty Factor," di Seminar Informatika Aplikatif Polinema, 2021, hal. 1-6.

[13] F. Z. Hidayah, "Penerapan Metode Case Based Reasoning dan Certainty Factor dalam Rancang Bangun Sistem Pakar Diagnosis Penyakit Diabetes Melitus Berbasis Mobile," UIN Maulana Malik Ibrahim, 2018.

[14] R. Andika, "Sistem Pakar Mendiagnosa Virus pada Udang Vannamei dengan Implementasi Metode CBR (Case-Based Reasoning) dan Certainty Factor," Jurnal Pelita Informatika, vol. 8, no. 2, 2019.

[15] B. R. Antika, Suharso, dan E. Nusantoro, "Studi Pengembangan Diri (Bakat Minat) pada Siswa Komunitas Sastra Di Thoyyibah Salatiga," Indonesian Journal of Guidance and Counseling: Theory and Application, vol. 2, no. 3, hal. 75-80, 2013.

[16] I. Sommerville, Software Engineering (Rekayasa Perangkat Lunak. Jakarta: Erlangga, 2011.

[17] Sugiyono, Metode Penelitian, 23 ed. Bandung: CV Alfabeta, 2016.

[18] D. Normawati dan S. A. Prayogi, "Implementasi Naive Bayes Classifier dan Confusion Matrix pada Analisis Sentimen Berbasis Teks pada Twitter," J-Sakti (Jurnal Sains Komputer dan Informatika), vol. 5, no. 2, hal. 697-711, 2021. 